\title{
PERAN WANITA DALAM MEMBANGUN EKONOMI RUMAH TANGGA MENURUT PERSPEKTIF ISLAM
}

\author{
Yasmin Aulia Fajrin \\ Universitas Pendidikan Indonesia \\ Email: yasminafjr@gmail.com \\ M. Abdul Somad \\ Universitas Pendidikan Indonesia \\ Email: somad100@upi.edu \\ Nurti Budiyanti \\ Universitas Pendidikan Indonesia \\ Email: nurtibudiyanti11.nb@gmail.com
}

\begin{abstract}
Abstrak
Pandangan mengenai wanita yang bekerja seringkali menimbulkan pro dan kontra di masyarakat. Hal ini timbul karena stereotip yang beredar di masyarakat bahwa wanita haruslah dengan baik mengurus rumah tangga, jika seorang wanita bekerja maka dikhawatirkan ia akan lalai dalam menjalankan tanggung jawabnya dalam rumah tangga. Padahal di zaman modern seperti sekarang, pandangan tersebut sudah bergeser seiring berkembangnya pola pikir masyarakat tentang peranan kaum wanita di masyarakat. Penelitian ini menggunakan pendekatan kualitatif deskriptif, dengan metode pengumpulan data kepustakaan yang bertujuan untuk memberikan pemahaman bagaimana peran wanita dalam membangun ekonomi rumah tangga. Data-data tersebut diperoleh dari dalil Al-Quran, Hadist, dan jurnal terkait peran wanita dan ekonomi Is lam. Kesimpulan yang didapat dari penelitian ini adalah Is la m memperbolehkan wanita untuk bekerja, selama pekerjaan tersebut tidak bertentangan dengan kodrat seorang wanita dan mendapat izin dari suami-nya. Seorang wanita yang bekerja harus mampu menjaga kehormatannya serta bisa membagi perannya dalam berkarir tanpa melupakan tanggung jawabnya dalam rumah tangga.
\end{abstract}

Kata kunci: wanita, ekonomi, rumah tangga, Islam.

\section{PENDAHULUAN}

Seiring berkembangnya zaman dan teknologi, pemikiran-pemikiran manusia pun berkembang pesat. Hal ini menimbulkan beberapa pergeseran makna dan stereotip yang beredar di masyarakat, begitu pula mengenai peran wanita di rumah tangga dan masyarakat. Di samping berkembangnya pemikiran masyarakat yang terbuka mengenai pekerjaan seorang wanita, masih banyak juga yang beranggapan bahwa wanita tidak boleh bekerja dan kewajibannya hanya seputar rumah tangga saja. Bentrokan pemikiran tersebut menimbulkan konflik dan perdebatan yang tidak ada habisnya hingga sekarang. Pada kenyataannya, di zaman sekarang banyak wanita yang turut andil dalam membantu ekonomi rumah tangganya dengan bekerja, bahkan beberapa terpaksa mencari nafkah sendiri untuk menghidupi keluarganya. 
Di Indonesia sendiri, isu ketidakadilan gender ini sebenarnya sudah mulai diperjuangkan sejak 1960-an dan membuat perubahan yang cukup signifikan. Gerakan ini timbul akibat meningkatnya kebutuhan keluarga dan kaum wanita yang semakin banyak mengenyam pendidikan. Kedudukan kaum wanita di masyarakat jadi membaik setelah gerakan ini muncul (Muhammad, 2019). Grant Thornton melakukan sebuah survey yang menunjukkan bahwa posisi senior pada perusahaan di dunia banyak diduduki oleh kaum wanita. Untuk tingkat global, Eropa Timur menjadi kawasan yang memberi kesempatan pada 35 persen kaum wanita untuk menjadi pemimpin di sebuah perusahaan. Sementara menurut indeks gender equality Indonesia di ASEAN dilihat dari partisipasinya dalam pasar tenaga kerja, sebanyak 30 persen kaum pria dan 70 persen kaum wanita menduduki sektor informal di ASEAN (Said, 2020).

Pergeseran mengenai peran wanita ini muncul akibat tuntutan-tuntutan baru di masyarakat seperti tanggapan bahwa wanita modern harus berpendidikan tinggi, berperan aktif, dan memiliki pemikiran kritis. Kebutuhan hidup yang meningkat membuat wanita tidak bisa bergantung pada pendapatan suami saja, kondisi ini mengharuskan mereka bekerja agar kebutuhan keluarganya tercukupi. Di samping kebutuhan tersebut, banyak pula wanita yang memang memilih untuk berkarir. Semakin tinggi pendidikan seorang wanita, maka keinginan untuk dirinya bekerja juga semakin besar.

Banyak faktor yang membuat wanita ingin terjun ke dunia pekerjaan. Faktor-faktor tersebut tentunya berhubungan dengan ambisi yang ada dalam diri seorang wanita, biasanya berkaitan dengan cita-cita, tujuan, rencana, dan motivasi untuk berkarya (Ermawati, 2016). Pembentukan aspirasi tersebut berkaitan dengan dua hal, yaitu; (1) keinginan untuk mengembangkan diri (adanya dorongan minat dan cita-cita individual), dan (2) keinginan untuk memenuhi tanggung jawab sesuai dengan apa yang diharapkan lingkungan sosial individu (Poerwandari, 1995).

Pekerjaan yang diambil oleh wanita biasanya terdapat di bidang-bidang yang berkaitan dengan sifat feminim dan bias gender, seperti bidang yang membutuhkan kelembutan, kesabaran, ketelitian, ketekunan dan hal lain yang diasosiasikan dan disosialisasikan sebagai sifat perempuan. Akibatnya muncul ketimpangan dalam pemberian upah antara kaum pria dan wanita. (Fatimah, 2015). Hal tersebut tentu menimbulkan gerakan perlawanan dari kaum wanita. Dari sinilah muncul istilah wanita karir. Wanita karir ini turut berperan di dalam tatanan masyarakat dengan bermacam fungsi dan jabatannya.

Wanita yang berperan ganda sebagai ibu rumah tangga dan pekerja memiliki tuntutan yang lebih dari biasanya. Selain tuntutan dalam pekerjaan, ia juga memiliki tanggung jawabnya untuk memenuhi kewajibannya sebagai istri atau bahkan ibu (Triaryati, 2003). Kondisi seperti ini seringkali menimbulkan permasalahan. Banyak wanita yang tidak mampu membagi waktunya 
dengan baik sehingga lalai menjalankan kewajiban pada salah satunya. Akibatnya, wanita yang bekerja seringkali tidak mempunyai waktu untuk keluarganya sehingga berdampak pada kurangnya kasih sayang yang diberikan pada anak-ananya. Begitu pula sebaliknya, wanita yang lebih memprioritaskan keluarga akan menurunkan kinerjanya dalam bekerja.

Dari penjelasan tersebut, dapat diambil kesimpulan bahwa sebenarnya keduanya memiliki peran yang sama sebagai istri dan ibu rumah tangga, yang berbeda hanya wanita yang bekerja memiliki kewajiban lain untuk bertanggungjawab pada pekerjaannya. Seorang wanita yang bekerja harus mampu menjalankan perannya dan tetap mengutamakan keluarganya. Karena pada dasarnya Islam sendiri menganjurkan wanita untuk menjaga keluarga dan rumah tangga, namun tidak juga melarang wanita untuk bekerja. Islam memperbolehkan wanita untuk bekerja dengan syarat-syarat berikut; (1) Wanita karier harus berjilbab dan menutup aurat, (2) Memiliki komitmen dengan akhlaqul karimah, menampakkan keseriusan dan sungguh-sungguh di dalam berbicara, dengan kata lain tidak dengan suara yang dibuat-buat, dan (3) Menjauhi pergaulan yang bersifat campur-baur atau berduaan dengan lawan jenis (Ermawati, 2016).

Fenomena ini tentunya menjadi topik yang menarik untuk diteliti. Melalui jurnal ini penulis ingin memberikan sedikit gambaran mengenai bagaimana Islam memandang wanita yang bekerja untuk membantu ekonomi rumah tangganya beserta solusinya agar wanita yang bekerja dapat tetap berkarir sekaligus berkeluarga.

\section{METODOLOGI}

Penelitian ini menggunakan pendekatan kualitatif deskriptif, dengan metode pengumpulan data kepustakaan yang diperoleh dari dalil Al-Quran, Hadist, dan jurnal terkait peran wanita dan ekonomi Islam. Penelitian ini memiliki ciri-ciri yaitu; (1) penelitian ini berhadapan langsung dengan teks dan angka, (2) data bersifat siap pakai, artinya peneliti dapat mengerjakan penelitian tanpa kemana-mana, dan (3) data umumnya bersumber dari data sekunder atau data yang diperoleh dari tangan kedua. Dari dasar-dasar tersebut penulis melakukan penelitian mengenai peran wanita dalam membangun ekonomi rumah tangga dalam Islam.

\section{HASIL DAN PEMBAHASAN}

Perubahan sosial yang cukup signifikat di setiap zamannya membuat pemikiran wanita yang semakin berkembang, ini menimbulkan keinginan bekerja yang semakin marak di kalangan wanita modern. Ada banyak faktor yang mempengaruhi keinginan seorang wanita ingin bekerja. Pada dasarnya, faktor-faktor tersebut meliputi (Latifah Qudsiah \& Gustiawati, 2017):

1. Untuk mencari kekayaan, biasanya dilakukan oleh wanita yang menganggap uang adalah segalanya. 
2. Untuk alasan ekonomis, agar wanita tidak bergantung pada suaminya walaupun suaminya tersebut mampu memenuhi kebutuhan rumah tangga.

3. Untuk mengamalkan ilmu dari pendidikan yang sudah ditempuh serta untuk menyalurkan potensi diri.

4. Untuk membantu suami yang kesulitan mencari nafkah keluarga.

Islam merupakan agama yang fleksibel. Islam tidak pernah melarang seorang wanita untuk bekerja selama kewajibannya yang lain tetap terpenuhi. Namun, tugas utama seorang istri tentulah berbakti kepada suami dan mendidik anak-anaknya. Kewajiban inilah yang seringkali diperdebatkan jika membahas tentang wanita yang bekerja. Masyarakat seringkali memandang wanita yang bekerja sebagai wanita yang lalai menjalankan kewajibannya. Padahal, bekerja juga merupakah suatu ibadah apalagi dengan niat membantu suami dalam mencari nafkah. Perbedaan pandangan masyarakat terhadap wanita pekerja ini seringkali menjadi konflik di masyarakat.

Konflik tersebut seringkali disebut dengan work family conflict. Work family conflict merupakan bentuk konflik peran dimana tuntutan peran dari pekerjaan dan keluarga secara mutual tidak bisa disejajarkan dalam berapa hal (Triaryati, 2003). Hal ini sering terjadi pada seseorang yang berusaha memenuhi tuntutan peran dalam pekerjaan dan usaha tersebut dipengaruhi oleh kemampuan orang tersebut dalam memenuhi tuntutan pekerjaannya (Frone, 2000).

Greenhaus dan Beutell (1985) mengidentifikasi tiga jenis work-family conflict, di antaranya:

1. Time-based conflict, waktu yang dibutuhkan untuk menjalankan salah satu tuntutan dapat mengurangi waktu untuk menjalankan tuntutan yang lain.

2. Strain-based conflict, terjadi pada saat tekanan dari salah satu peran mempengaruhi kinerja peran lainnya.

3. Behaviour-based conflict, biasanya berhubungan dengan ketidaksesuaian antara pola perilaku dengan yang diinginkan oleh kedua peran.

Terlepas dari pro dan kontra tentang peran wanita yang bekerja, peran wanita yang bekerja dalam sebuah keluarga atau rumah tangga memberikan pengaruh yang cukup besar (Said, 2020), di antaranya:

1. Wanita yang bekerja di sebuah keluarga atau rumah tangga menjadi penting karena dapat membantu meringankan beban tanggungan seorang suami dalam memenuhi kebutuhan sehari hari.

2. Wanita yang bekerja biasanya lebih produktif karena memanfaatkan waktunya dengan hal-hal yang berguna seperti bekerja dan mengurus rumah tangga. 
3. Beberapa peran tidak bisa dikerjakan dengan kaum laki-laki. Sehingga peran wanita di masyarakat sangat penting untuk menjaga tatanan sosial di masyarakat.

Namun, di sisi lain wanita yang bekerja juga memiliki dampak negatifnya pada rumah tangga (Ermawati, 2016), seperti:

1. Seorang ibu yang bekerja, akan memiliki waktu yang sedikit untuk mengurus dan mendidik anak, sementara seorang anak sangatlah membutuhkan kasih sayang dari ibunya. Peran seorang ibu yang hilang ini seringkali digantikan dengan orang lain. Hal ini bisa berdampak bahaya pada anak jika diabaikan, seperti tidak harmonisnya hubungan antara ibu dan anak, atau bahkan anak tersebut melakukan tindakan di luar norma karena kurangnya pengawasan terhadap anak.

2. Pekerjaan rumah menjadi terbengkalai. Seringkali wanita yang bekerja kesulitan membagi waktu dalam mengerjakan tugas rumah tangga seperti mencuci baju atau membersihkan rumah. Masalah ini bisa saja diselesaikan dengan menyewa pembantu rumah tangga. Namun hal-hal seperti melayani suami tidak bisa digantikan perannya dengan orang selain istri sah-nya.

3. Komunikasi dengan anak dan suami bisa saja terganggu karena wanita tersebut bekerja. Jika sudah bekerja, seorang wanita bisa saja sibuk sehingga mengurangi intensitas komunikasi dengan keluarganya. Padahal, komunikasi sangat penting dalam keharmonisan sebuah keluarga.

Dalam Islam sendiri, kewajiban mencari nafkah merupakan kewajiban seorang pria sebagai kepala keluarga. Wanita boleh saja bekerja, asalkan tidak melanggar ketentuan-ketentuan yang melanggar syari'at (Toha et al., 2016). Dalam surat At-Taubah ayat 105, dikatakan bahwa:

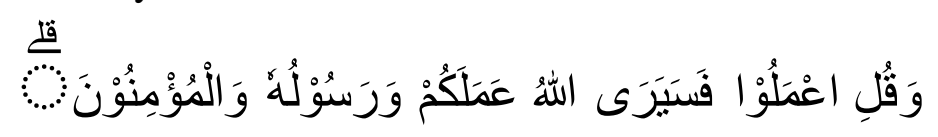

Artinya: "Katakanlah (wahai Muhammad), bekerjalah kalian! Maka Allah, Rasul-Nya, dan para mukminin akan melihat pekerjaanmu” (QS At-Taubah:105).

Perintah tersebut berlaku untuk pria dan wanita. Allah juga mensyariatkan untuk bekerja kepada hamba-Nya karena manusia diperintahkan untuk berikhtiar dan bekerja. Dalam surat An-Nisa ayat 29 Allah berfirman:

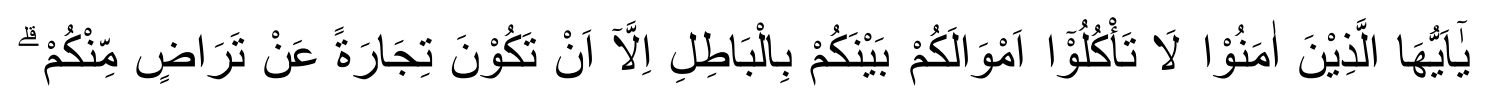

Artinya: "Wahai orang-orang yang beriman, janganlah kalian saling memakan harta sesama kalian dengan jalan yang tidak benar, akan tetapi hendaklah kalian berdagang atas dasar saling rela di antara kalian.” (Q.S. An-Nisa:29).

Sementara menurut pandangan Islam tradisional, pria merupakan kepala keluarga dan bertanggung jawab terhadap urusan di luar rumah, sementara wanita berperan sebagai istri yang bertanggung 
jawab membesarkan anak dan melayani suami. Hal tersebut menjadi parameter peran pria dan wanita dalam rumah tangga, seperti yang disebutkan dalam surat An-Nisa ayat 34:

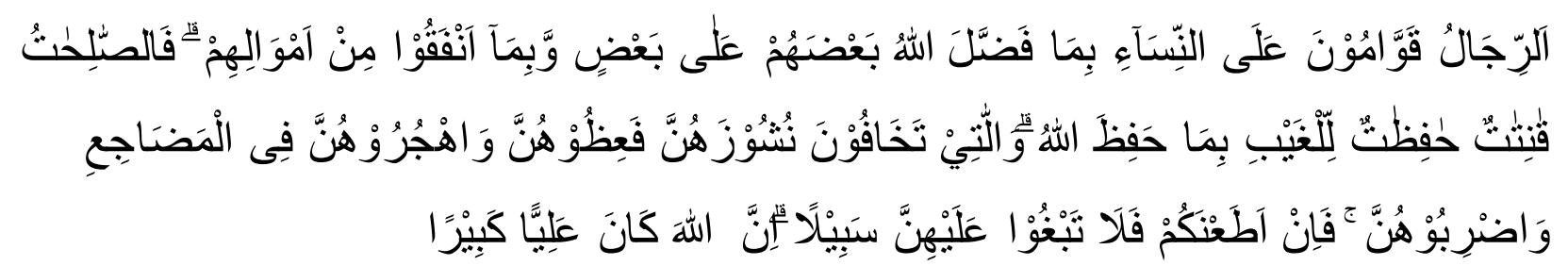

Artinya: "Laki-laki (suami) itu pelindung bagi perempuan (istri), karena Allah telah melebihkan sebagian mereka (laki-laki) atas sebagian yang lain (perempuan), dan karena mereka (laki-laki) telah memberikan nafkah dari hartanya. Maka perempuan-perempuan yang saleh adalah mereka yang taat (kepada Allah) dan menjaga diri ketika (suaminya) tidak ada, karena Allah telah menjaga (mereka). Perempuan-perempuan yang kamu khawatirkan akan nusyuz, hendaklah kamu beri nasihat kepada mereka, tinggalkanlah mereka di tempat tidur (pisah ranjang), dan (kalau perlu) pukullah mereka. Tetapi jika mereka menaatimu, maka janganlah kamu mencari-cari alasan untuk menyusahkannya. Sungguh, Allah Mahatinggi, Mahabesar.” (Q.S. An-Nisa:34).

Dari ayat-ayat di atas, dapat disimpulkan bahwa dalam Islam, pria dan wanita memiliki kedudukan yang sama. Setiap individu memiliki kewajibannya masing-masing dan harus dilaksanakan dengan ikhlas. Di samping kewajiban tersebut tentunya setiap individu memiliki hak-hak yang akan mereka dapatkan. Selanjutnya seorang individu turut serta dalam menjaga keluarga dengan menjalankan kewajiban-kewajiban yang ada di dalamnya atas dasar hormat dan kasih sayang. Selain di keluarga, setiap individu juga memiliki perannya masing-masing di masyarakat.

Jadi, sebagai seorang wanita tentu boleh saja bekerja, asalkan dengan izin dari suami atau wali-nya. Suami boleh melarang istrinya untuk tidak bekerja jika pekerjaan yang dilakukan membawa kemudharat-an bagi diri dan keluarganya. Namun jika tujuannya untuk mencari nafkah karena suami tidak mampu bekerja karena sakit atau miskin, maka suami tidak boleh melarang.

Selain itu terdapat syarat-syarat lain agar seorang wanita diperbolehkan untuk bekerja (Toha et al., 2016), diantaranya:

1. Tidak meninggalkan tugas utamanya sebagai istri dan ibu rumah tangga.

2. Diizinkan oleh suami.

3. Tidak bekerja di tempat yang lelaki dan wanitanya saling berbaur.

4. Tidak melakukan pekerjaan yang merusak kepribadian Muslimah.

5. Menjaga aurat dan kesucian diri.

Selain itu, ada beberapa hal yang dapat dilakukan oleh wanita untuk menghindari konflik rumah tangga dan pekerjaan (Ermawati, 2016), antara lain: 
1. Memilih pekerjaan yang jauh dari mudharat.

2. Memilih pekerjaan yang sesuai dengan kodrat seperti di bidang pendidikan atau kesehatan ibu dan anak.

3. Memilih pekerjaan dengan waktu yang sesuai agar pekerjaan rumah tangganya tidak terabaikan.

4. Memiliki jadwal khusus untuk suami dan keluarga untuk menjaga keharmonisan.

5. Tidak terlalu ambisius dalam karir karena dikhawatirkan akan meninggalkan kewajibannya yang lain, namun juga tidak menahan diri untuk mengembangkan potensi diri.

Dengan begitu, sudah jelas Islam tidak pernah melarang wanita untuk bekerja seperti yang disebutkan oleh beberapa kalangan. Islam memperbolehkan wanita untuk mengejar karir dan membangun ekonomi keluarganya. Nabi Muhammad SAW pernah bersabda "Sebaik-baiknya canda seorang Muslimah di rumahnya adalah bertenun", ini menyiratkan bahwa walaupun di rumah seorang wanita juga harus tetap berkarya. Selain itu, faktor lain yang perlu dipertimbangkan adalah kesanggupannya untuk bekerja. Seorang wanita yang berkarir harus mampu menjalankan pekerjaannya berikut dengan konsekuesinya. Ini penting karena wanita sangat rawan dilecehkan, sehingga akan lebih baik jika memilih pekerjaan yang aman bagi wanita tersebut. Islam juga telah mempermudah jalan bagi mereka untuk membangun keluarga yang harmonis, di samping itu akan terbentuk keluarga yang sakinah, mawadah, wa rahmah. Hal tersebut terwujud jika perempuan tersebut berhasil menjalankan kewajibannya sebagai pekerja dan ibu rumah tangga. Selain itu, Islam juga memberi kesempatan pada wanita untuk turut berperan dalam aktivitas ekonomi termasuk untuk memilih pekerjaan yang sesuai dengan syari'at Islam.

\section{PENUTUP}

\section{Kesimpulan}

Dengan bergantinya pemikiran mengenai peran wanita di masyarakat, keinginan wanita modern untuk bekerja semakin meningkat. Ada banyak faktor yang mempengaruhi hal tersebut, seperti faktor kebutuhan ekonomi dan individu yang timbul akibat keinginan untuk mengembangkan potensi diri. Di sisi lain, hal tersebut menimbulkan kontra karena dikhawatirkan wanita tersebut akan mengabaikan perannya sebagai seorang istri dan ibu rumah tangga. Jika tanggung jawabnya di rumah tangga tidak terpenuhi, maka akan menimbulkan ketidakharmonisan keluarga akibat berkurangnya waktu berharga dengan suami dan anak. Dalam Islam sendiri, diperbolehkan bagi seorang wanita untuk bekerja asalkan diizinkan oleh suami dan tidak lupa dengan tanggung jawabnya dalam rumah tangga, juga memilih pekerjaan yang tidak membawa mudharat bagi diri dan keluarganya. 


\section{Saran}

Wanita yang bekerja sebaiknya tidak meninggalkan kewajibannya dalam rumah tangga dan tidak pula lalai menjalankan pekerjaannya. Seorang wanita yang bekerja harus mampu menyeimbangkan keduanya, dengan memandang dua-duanya sebagai prioritas yang sama dan tidak dibeda-bedakan. Selain itu hendaknya wanita yang bekerja senantiasa menaati syari'at yang sudah ada agar terhindar dari fitnah.

\section{DAFTAR RUJUKAN}

Ermawati, S. (2016). PERAN GANDA WANITA KARIER (Konflik Peran Ganda Wanita Karier ditinjau dalam Prespektif Islam). JURNAL EDUTAMA, 2(2), 59-69.

Fatimah, T. (2015). WANITA KARIR DALAM ISLAM. MUSAWA, 7(1), 29-51.

Latifah Qudsiah, W., \& Gustiawati, S. (2017). Peranan Wanita Karir Dalam Membantu Kebutuhan Keluarga Menurut Mazhab Syafi-iyyah. MIZAN: Journal of Islamic Law, 1(2), 155-172. https//doi.org/https://doi.org/10.32507/mizan.v1i2.10 Abstract:

Muhammad, I. (2019). Wanita Karir Dalam Pandangan Islam. Al-wardah: Jurnal Kajian Perempuan, Gender dan Agama, 13(1), 107-116. https://doi.org/10.46339/alwardah.v13i1.161

Poerwandari, E. K. (1995). Aspirasi dan aktualisasi aspirasi perempuan muda yang bekerja : kajian kualitatif. T. O Ihromi (ed), dkk, Kaji-an Wanita dalam Pembangunan, 81868.

Said, D. H. (2020). PERAN ISTRI DALAM MEMBANGUN EKONOMI KELUARGA MENURUT PERSPEK TIF HUKUM ISLAM DI KECAMATAN PANYABUNGAN KOTA. AT-TAWASSUTH: Jurnal Ekonomi Islam, V(2), 268-290.

Toha, M., Hasan, K., \& Fatkhurrozi, T. (2016). PERAN WANITA KARIR DALAM EKONOMI ISLAM. AL-'ADALAH: Jurnal Syariah dan Hukum Islam, 1(3), 50-63.

Triaryati, N. (2003). Pengaruh Adaptasi Kebijakan Mengenai Work Family Issue Terhadap Absen Dan Turnover. Jurnal Manajemen \& Kewirausahaan, 5(1), 85-96. https:/doi.org/https://doi.org/10.9744/jmk.5.1.pp.\%2085-96 